\title{
THE REMOVAL OF OXYTETRACYCLINE (OTC) BY POTASSIUM FERRATE (VI) IN AQUATIC ENVIRONMENT
}

ZENG F.C.

LIU Y.B.

WANG H.Y.*

Received: 02/03/2016

Accepted: $12 / 05 / 2016$

Available online: $17 / 05 / 2016$
College of Civil Engineering and Architecture

Zhejiang University of Technology

Hangzhou 310014, People's Republic of China

*to whom all correspondence should be addressed: e-mail: hywang@zjut.edu.cn

\section{ABSTRACT}

The treatment of oxytetracycline (OTC) in test solutions by ferrate (VI) was investigated aiming to propose the effects of $\mathrm{pH}$, concentration of co-existing ions and humic acid on the OTC removal. Ferrate (VI) can remove $97 \%$ OTC (from $1000 \mu \mathrm{g} \cdot \mathrm{l}^{-1}$ ) in 30 minutes under the optimal conditions with solution $\mathrm{pH}$ of 7 and ferrate (VI) dosage of 20:1 as a molar ratio of ferrate (VI)/OTC. The effects of co-existing ions $\left(0.005 \mathrm{~mol} \cdot \mathrm{I}^{-1}\right.$ and $\left.0.02 \mathrm{~mol} \cdot \mathrm{l}^{-1}\right)$ and humic acid $\left(\left.0.1 \sim 50 \mathrm{mg} \cdot\right|^{-1}\right)$ on the OTC removal were investigated for the optimal operating conditions. The results showed that $\mathrm{Ca}^{2+}, \mathrm{CO}_{3}{ }^{2-}, \mathrm{PO}_{4}{ }^{3-}$ could inhibit the OTC degradation and its removal rate decreased from $79,29,29 \%$ to $70,19,19 \%$, for the ion concentration increased from 0.005 $\mathrm{mol} \cdot \mathrm{l}^{-1}$ to $0.02 \mathrm{~mol} \cdot \mathrm{l}^{-1}$. $\mathrm{Mg}^{2+}$ and $\mathrm{HCO}_{3}{ }^{-}$could restrain the reaction carried out at $0.02 \mathrm{~mol} \cdot \mathrm{l}^{-1}$ and the removal rate was only $59 \%, 62 \%$. $\mathrm{Al}^{3+}$ could increase the removal rate which reach to $100 \%$. Humic acid with concentrations of greater than $10 \mathrm{mg} \cdot \mathrm{l}^{-1}$ could notably inhibit the OTC removal. Regression analysis indicated good fit of the experimental date to the developed model with coefficient of determination $\left(R^{2}\right)$ value of 0.9991 and the adjusted $R^{2}$ value of 0.9978 .

Keywords: ferrate (VI); oxytetracycline; humic acid; co-existing ions; Box-Behnken design;

\section{Introduction}

Oxytetracycline (OTC) is a common broad-spectrum antibiotic tetracycline. It is widely used in swine, cattle, poultry and fish husbandry as feed additives and veterinary drugs for prophylactic, and therapeutic purposes throughout the world, because of its low cost and effective antimicrobial (Lu et al., 2015). However, the widespread use of it has led to much environmental issues and human health problems (Marx et al., 2015; Li et al., 2015; Burkina et al., 2015; Auerbach et al., 2007; Luis Martinez, 2009), such as the presence of OTC residues in animal foods and environmental pollution (Kim et al., 2014; Fritz et al., 2007; Sun et al., 2014). Most of OTC leaves human and animal body unmetabolized via feces and urine (Liu et al., 2015; Kemper, 2008).Therefore OTC is extensively distributed in soil, groundwater, surface water, sea water, and sediment worldwide (Shibata et al., 2014; Chen et al., 2015; Kuemmerer, 2009). Moreover, the nature of OTC is stable and difficult to be degraded; therefore it can exist in the natural environment for a long time. Its occurrence in natural environment may have harmful impact on human health and ecosystem through the development of drug resistance among pathogens and bacteria. Therefore it is important to remove the pollutant from

Zeng F.C., Liu Y.B. and Wang H.Y. (2016), The removal of oxytetracycline (OTC) by Potassium Ferrate (VI) in aquatic environment, Global NEST Journal, 18(2), 381-391. 
wastewater before discharging into the environment. Several studies have shown that OTC is hardly degraded by conventional water treatment process (Watkinson et al., 2007; Rahmah et al., 2015).

Ferrate (VI) is a strong oxidant in aqueous media with a reduction potential of $2.20 \mathrm{~V}$ and $0.70 \mathrm{~V}$ in acidic and alkaline, respectively; under acidic conditions, the redox potential of ferrate (VI) ion is strongest among all oxidants/disinfectants used for water and wastewater treatment (Jiang, 2014). It is also an environmentfriendly chemical for coagulation, disinfection, and oxidation for multipurpose treatment of water and wastewater; during the oxidation/disinfection process, ferrate (VI) ions are reduced to Fe (III) or ferric hydroxide, and this simultaneously generates a coagulant in a single dosing and mixing unit process (Jiang et al., 2012). Furthermore, the application of ferrate (VI) can improve the removal of nature organic matter or disinfection byproducts (DBPs) precursors (Sharma et al., 2006). There are many processes have been investigated on the degradation of OTC, such as ozone process, Fenton process, UV photolysis, simulated sunlight irradiation (Uslu et al., 2009; Yuan et al., 2011; Chen et al., 2008; Li et al., 2008). However, no study has been reported on the removal of OTC using ferrate (VI).

Therefore, the objectives of this study were to find the best reaction time, ferrate (VI) dose and the $\mathrm{pH}$ value of reaction solution on the removal of OTC; to assess the influence of the type and strength of coexisting ions on the removal of OTC; to evaluate the effect of humic acid on the removal of OTC and finally to identify the optimal operating conditions to degraded the OTC by ferrate (VI).

\section{Experimental section}

\subsection{Chemicals and reagents}

The OTC was purchased from Aladdin (Shanghai, China); acetonitrile (HPLC grade) was purchased from Tianjin Shiyou Chemical Reagent Factory (Tianjin, China) and potassium hydroxide (AR) was purchased from Hangzhou Xiaoshan Chemical Reagent Factory (Hangzhou, China). Humic acid was obtained from Nanjing Chemical Reagent Factory (Nanjing, China). Ferrate (VI) solution of high concentration was synthesized by the electro-chemical method (Wang et al., 2015), and the solid potassium ferrate (VI) was obtained after various purification steps (Li et al., 2005). The ferrate (VI) strength of the resulting dry product was measured by chromite method and direct spectrophotometric method using a wavelength of $505 \mathrm{~nm}$ and an absorbance coefficient of $1100 \mathrm{M}^{-1} \cdot \mathrm{cm}^{-1}$ (Jiang et al., 2006). The purity of ferrate (VI) was continuously monitored on the daily basis. The other reagents (AR) were supplied by Sinopharm Chemical Reagent Co., Ltd. (Shanghai, China). Experimental water was generated by ultra pure water supplier (UPHW1-90T, Sichuan europtronic ultra pure Technology Co. Ltd., China). Stock solutions of OTC were prepared in pure water at $\left.100 \mathrm{mg} \cdot\right|^{-1}$ for the use of jar test experiments.

\subsection{Jar test experiment}

The oxidation of OTC by ferrate (VI) was studied using a magnetic stirrer (HJ-6, Jintan Jiangnan instrument Factory), with a mixing speed of $500 \mathrm{rpm}$. Transfer liquid pipette (Shanghai Kangmin inspection equipment Co. Ltd, China) was used for sampling at given reaction time intervals and sodium thiosulfate $\left(0.1 \mathrm{~mol} \cdot \mathrm{I}^{-1}\right)$ was used as a quencher.

The influence of operating conditions were investigated using $100 \mathrm{~mL}$ test solutions with initial OTC concentrations of $1000 \mu \mathrm{g} \cdot \mathrm{l}^{-1}$ and by adjusting the ferrate (VI) dosages, $\mathrm{pH}$ value and humic acid concentrations. Ferrate (VI) was dosed into the test solution as dried powder and the dosage applied was in the molar ratio of ferrate $(\mathrm{VI}) / O T C$ from $5: 1$ to $50: 1$. The $\mathrm{pH}$ value of test solutions was adjusted by $0.01 \mathrm{~mol} \cdot \mathrm{I}^{-}$

${ }^{1}$ sulfuric acid and $0.01 \mathrm{~mol} \cdot \mathrm{I}^{-1}$ potassium hydroxide to $\mathrm{pH} 5 \sim 10$. The humic acid concentration in testing solutions was $\left.0.1 \sim 50 \mathrm{mg} \cdot\right|^{-1}$. The OTC concentration and removal percentage of each sample were detected by liquid chromatography (LC) (see sub-section 2.3). 
$100 \mathrm{ml}$ test solutions with OTC initial concentration of $1000 \mu \mathrm{g} \cdot \mathrm{l}^{-1}$ were used to study the impact of the presence of $0.005 \mathrm{~mol} \cdot \cdot^{-1}$ and $0.2 \mathrm{~mol} \cdot \cdot^{-1}$ co-existing ions $\left(\mathrm{Na}^{+}, \mathrm{Mg}^{2+}, \mathrm{Ca}^{2+}, \mathrm{Al}^{3+}, \mathrm{CO}_{3}{ }^{2-}, \mathrm{SO}_{4}{ }^{2-}, \mathrm{PO}_{4}{ }^{3-}, \mathrm{Cl}^{-}, \mathrm{NO}_{3}{ }^{-}\right.$, $\mathrm{HCO}_{3}{ }^{-}$) on the OTC degradation performance by ferrate (VI). The OTC solutions were mixed with given amount of $\mathrm{NaCl}, \mathrm{KCl}, \mathrm{KNO}_{3}, \mathrm{Mg}\left(\mathrm{NO}_{3}\right)_{2}, \mathrm{CaCl}_{2}, \mathrm{Al}_{2}\left(\mathrm{SO}_{4}\right)_{3}, \mathrm{Na}_{2} \mathrm{CO}_{3}, \mathrm{Na}_{2} \mathrm{SO}_{4}, \mathrm{NaHCO}_{3}$ and $\mathrm{Na}_{3} \mathrm{PO}_{4}$, respectively, to achieve the required ion concentrations. The ferrate (VI) with dosage of 20:1 as ferrate (VI)/OTC in the molar ratio was mixed with the test solution and the sampling time was 30 minutes. All samples in experiments were filtered by $0.45 \mu \mathrm{m}$ glass membrane filters (Shanghai Xingya purifying material factory, China) before analyzing the residual OTC concentrations. The OTC concentration and removal rate of each sample were detected by high performance liquid chromatography (HPLC) (Agilent 1200 series, USA) (see sub-section 2.3).

\subsection{Detection Method}

The quantification of OTC was measured by an Agilent 1200 Series HPLC system equipped with a UV detector. A C18 Eclipse XDB (Supelco) column (150 mm× $4.6 \mathrm{~mm}, 5 \mu \mathrm{m}$ particle size) was used as a stationary phase. The mobile phase for OTC was $0.1 \%$ oxalic acid water solution /acetonitrile $(82 / 18, \mathrm{v} / \mathrm{v} \%)$ at a flow rate of 0.5 $\mathrm{ml} \cdot \mathrm{min}^{-1}$. The detection wavelength was set at $360 \mathrm{~nm}$, the sample injection volume was $10 \mu \mathrm{l}$ and the column temperature was kept at $30^{\circ} \mathrm{C}$. The $\mathrm{pH}$ value was measured using a portable $\mathrm{pH}$ meter (SensION, HACA, USA).

\subsection{Box-Behnken experimental design}

Response surface methodology is an empirical modeling technique used to evaluate the relationship between a set of controllable experimental factors and observed results (Mourabet et al., 2012). In this study, the BoxBehnken (BBD) was used to design the experiment. The most important factors, which affect the efficiency of OTC removal extremely, are contact time, ferrate $(\mathrm{VI})$ dose and $\mathrm{pH}$. Therefore the three parameters are the contact time (min), ferrate ( $\mathrm{VI})$ dose (Fe(VI)/OTC in molar ration) and $\mathrm{pH}$, represented as $\mathrm{X}_{1}, \mathrm{X}_{2}$, $\mathrm{X}_{3}$, separately. A three-factor, three-level second-order model was developed. The OTC removal ( $Y$ ) was considered the response. Experimental range and the levels of the independent variables are showed in Table 1 . This design was applied using Design-Expert 8.0.6.1 to the study. The following equation represents a second-order model (Equation 1):

$Y=\beta_{0}+\beta_{i}+x_{i}+\Sigma \beta_{i i}+x_{i i}{ }^{2}+\Sigma \beta_{i j x i x j}+\varepsilon$

Where, $Y$ is the predicted response surface function, $\beta_{0}$ is the model constant, $\beta_{i}$ is the slope or linear effect of the input factor $x_{i}, \beta_{i j}$ is the quadratic effect of input factor $x_{i}$ and $\beta_{i j}$ is the linear by linear interaction effect between the input factor $x_{i}$ and factor $x_{j}$ (Mourabet et al., 2012).

Table 1. Experimental range and levels of independent variables

\begin{tabular}{ccccc}
\hline & \multirow{2}{*}{ Independent Variables } & \multicolumn{3}{c}{ Range and level } \\
\cline { 3 - 5 } & contact time $(\mathrm{min})$ & $\mathbf{- 1}$ & $\mathbf{0}$ & $\mathbf{+ 1}$ \\
\hline $\mathrm{X}_{1}$ & Ferrate $(\mathrm{VI})$ dose & 10 & 20 & 30 \\
\hline $\mathrm{X}_{2}$ & $\mathrm{pH}$ & $15: 1$ & $20: 1$ & $25: 1$ \\
\hline $\mathrm{X}_{3}$ & & 6 & 7 & 8 \\
\hline
\end{tabular}

\section{Results and Discussion}

\subsection{Effect of reaction time and ferrate (VI) dosage}

The ferrate (VI) dosage ranged from 5:1 to 25:1 as molar ratio of [ferrate (VI)/OTC] and the reaction time was 60 minutes. Fig. 1 shows that most OTC was degraded in 5 minutes. Along with the time, the concentration of OTC decreased slowly and at the time of 30 minutes, the reaction finished. From 30 minutes to 60 minutes, the OTC concentration did not change. Therefore the optimum reaction time is 30 minutes. 
In order to obtain the best dosage of ferrate (VI), dosage was increased from 5:1 to 50:1 as [ferrate (VI)/OTC] in molar ratio. Fig. 2 shows that the average removal efficiency of OTC in the model wastewater was $88 \%^{\sim 97 \% \text {. }}$ It's obviously that with the increase of the ferrate (VI) dosage, the removal rate gradually increased, however the removal rate increased slowly when the dosage range from 15:1 to 50:1 as [ferrate (VI)]/[OTC]. Moreover, the removal rate slightly decreased if the dosage reaches to 50:1.This indicates that the OTC unit degradation performance at high ferrate (VI) dose was not as high as that at low ferrate (VI) dose. It could be that the ferrate (VI) decomposed and the ferrate (VI) decomposition speed increased when the dosage of ferrate (VI) increased (Sharma et al., 2006). The best ferrate (VI) dosage ranged from 10:1 to 25:1 as [ferrate (VI)]/[OTC] and thus for the subsequent experiments, a dose of $20: 1$ as [Ferrate (VI)]/[OTC] in molar ratio was chosen.

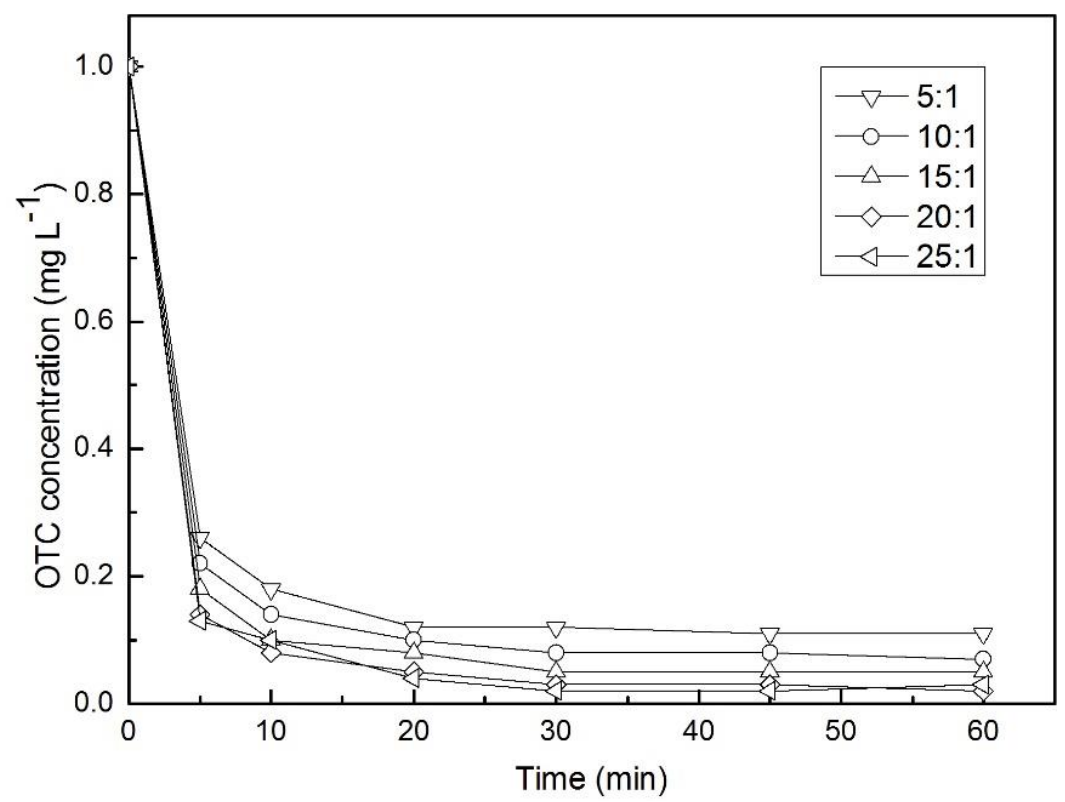

Figure 1. Effect of reaction time on the oxidation of OTC with ferrate (VI)

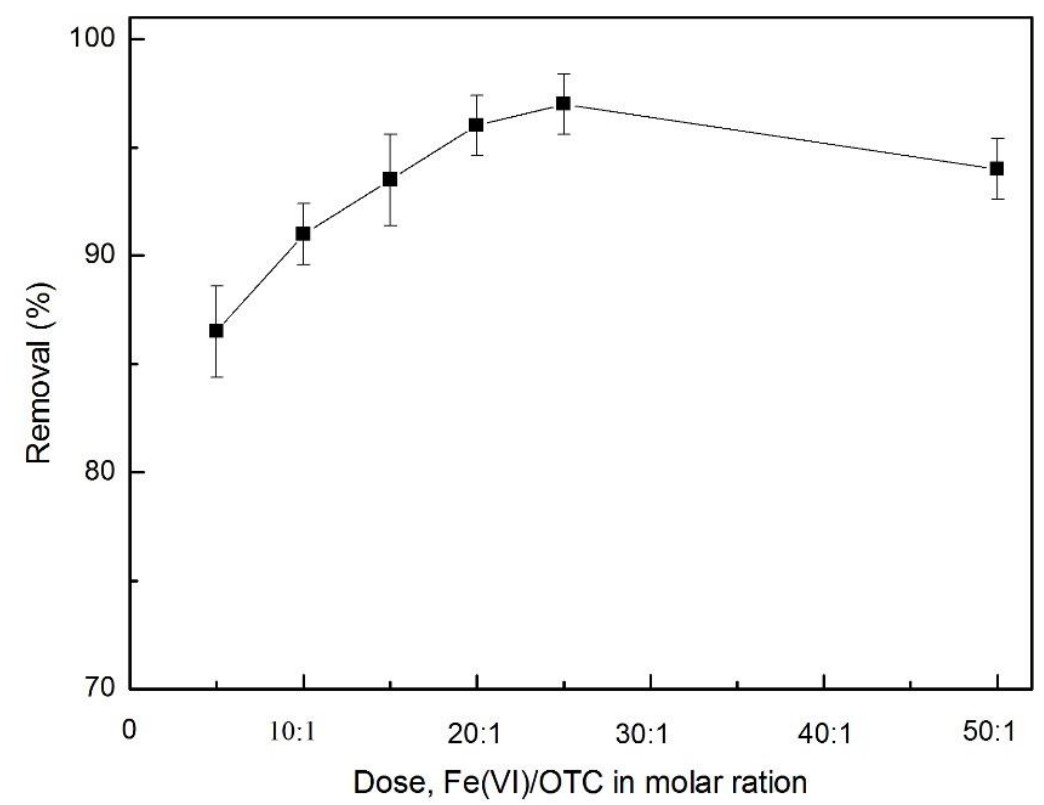

Figure 2. Effect of different dosage of ferrate (VI) on the oxidation of OTC 


\subsection{Influence of $\mathrm{pH}$}

The initial concentration of OTC was $1000 \mu \mathrm{g} \cdot \mathrm{l}^{-1}$, and the $\mathrm{pH}$ was adjusted to between 5 and 10; the reaction time was 30 minutes, and the dosage of [ferrate (VI)]/[OTC] was 20:1 in molar ratio. Fig.3 shows that the pH of the solution has a great influence on the removal of OTC. Under neutral and faintly acid conditions, the removal efficiency of OTC is significantly higher than in alkaline conditions. When the $\mathrm{pH}$ value of solution was 7 , the OTC removal was $97 \%$.This is mainly because the $\mathrm{pH}$ of the reaction solution will affect the stability and oxidation ability of ferrate $(\mathrm{VI})$; Moreover, with the increase of the $\mathrm{pH}$, the redox potential of ferrate (VI) becomes more and more weak, so the reaction rate and removal efficiency of OTC become lower and lower. On the other hand, with the decrease of the $\mathrm{pH}$, the ferrate (VI) solution becomes more and more unstable. When the $\mathrm{pH}$ value of the reaction solution changes from 5 to 7, ferrate (VI) mainly exits in the form of $\mathrm{HFeO}_{4}{ }^{-}$ and $\mathrm{H}_{2} \mathrm{FeO}_{4}$ (Eq. (2)-(4)). Ferrate (VI) is unstable and prone to self decomposition and then the removal efficiency of OTC becomes low. Moreover, OTC has three ionization equilibriums (Jiao et al., 2008; Figueroa et al., 2004). When pH is neutral or weak acid, the dissociation degree of OTC is higher. Studies have shown that the organic matter of dissociation state is more likely to be oxidized (Li et al., 2005); therefore the OTC can be oxidized by ferrate (VI) easily.

$$
\begin{aligned}
& \mathrm{H}_{3} \mathrm{FeO}_{4}{ }^{+} \longleftrightarrow \mathrm{H}^{+}+\mathrm{H}_{2} \mathrm{FeO}_{4}, \mathrm{pK}_{\mathrm{a}}=1.6 \pm 0.2 \\
& \mathrm{H}_{2} \mathrm{FeO}_{4} \longleftrightarrow \mathrm{H}^{+}+\mathrm{HFeO}_{4}{ }^{-}, \mathrm{pK}_{\mathrm{a}}=3.5 \\
& \mathrm{HFeO}_{4}{ }^{-} \longleftrightarrow \mathrm{H}^{+}+\mathrm{FeO}_{4}{ }^{2-}, \mathrm{pK}_{\mathrm{a}}=7.3 \pm 0.1
\end{aligned}
$$

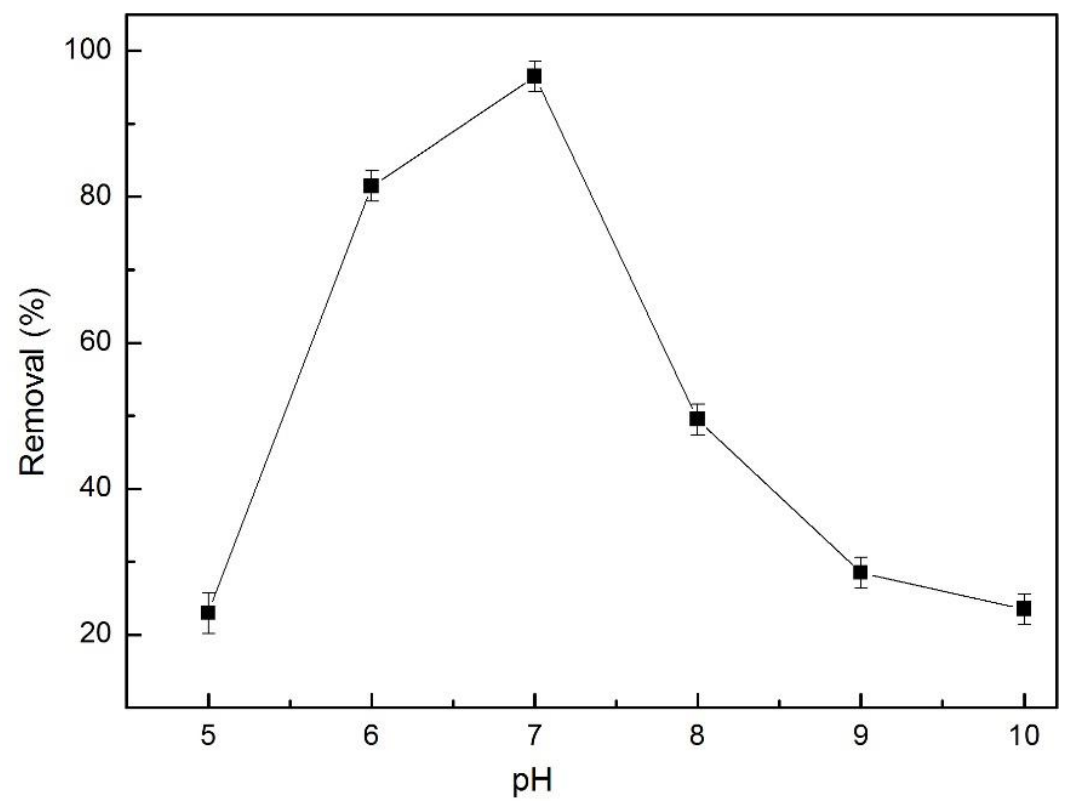

Figure 3. Effect of $\mathrm{pH}$ value on the oxidation of OTC with ferrate (VI)

\subsection{Influence of the type and strength of coexisting ions}

There are numerous types of ions in natural water bodies. Because of their different valence states, alkaline activity and other property, they have different effects on the reaction process. In order to investigate the influence of different types of ions and concentrations on the oxidation of OTC with ferrate (VI), the chloride 
$(\mathrm{Cl})$, nitrate $\left(\mathrm{NO}_{3}{ }^{-}\right)$, carbonate $\left(\mathrm{CO}_{3}{ }^{2-}\right)$, sodium $\left(\mathrm{Na}^{+}\right)$, bicarbonate $\left(\mathrm{HCO}_{3}{ }^{-}\right)$, aluminum $\left(\mathrm{Al}_{3}{ }^{+}\right)$, sulfate $\left(\mathrm{SO}_{4}{ }^{2-}\right)$, magnesium $\left(\mathrm{Mg}_{2}{ }^{+}\right)$, calcium $\left(\mathrm{Ca}^{2+}\right)$ and phosphate $\left(\mathrm{PO}_{4}{ }^{3-}\right)$ were selected for the study. The ion concentration was $0.005 \mathrm{~mol} \cdot \mathrm{f}^{-1}$ and $0.02 \mathrm{~mol} \cdot \mathrm{l}^{-1}$ respectively. Fig.4 shows that ions of phosphate, calcium, carbonate, magnesium, bicarbonate, aluminum have an effect on the degradation of OTC. Calcium, carbonate, phosphate can inhibit the reaction carried out: when the ions' concentration was $0.005 \mathrm{~mol} \cdot \mathrm{I}^{-1}$, the removal rate was $79,29,29 \%$ and decreased to $70,19,19 \%$ when the ions' concentration reached to $0.02 \mathrm{~mol} \cdot \mathrm{I}^{-1}$. The inhibition ability of phosphate and carbonate is stronger than calcium ion. Magnesium ion and bicarbonate only can slow down the reaction when its concentration was 0.02 $\mathrm{mol} \cdot \mathrm{l}^{-1}$ and the removal rate was only $59 \%, 62 \%$. It is mainly because calcium ion and magnesium ion can form complex with OTC (Paroloa et al., 2012; Cesaretti et al., 2014) and the complex hinder the reaction of oxidation of OTC with ferrate (VI). Carbonate and bicarbonate are known as free radical scavenger; therefore they can reduce the OTC removal rate. It has also reported that bicarbonate can form inner-sphere monodentate complexes with surface functional groups of $\mathrm{Fe}(\mathrm{OH})_{3}$ (Su et al., 1997), therefore bicarbonate ions and OTC will competitively react with $\mathrm{Fe}(\mathrm{OH})_{3}$, which lead to the amount of $\mathrm{Fe}(\mathrm{OH})_{3}$ decreased which could play roles to adsorb OTC. Phosphate can form complex with $\mathrm{Fe}^{3+}$, resulting from the ferrate (VI) decomposition, which inhibit the hydrolysis of $\mathrm{Fe}^{3+}$ and then reduce the generation of $\mathrm{Fe}(\mathrm{OH})_{3}$. Aluminum ion can increase the degradation rate of OTC, which reach to $100 \%$. This could attribute to that the particle size of the Fe(III)-Al(III) oxy/hydroxide precipitates is smaller than Fe (III) oxy/hydroxide leading to higher surface area and more adsorption sites available for OTC retention (Jain et al., 2009).

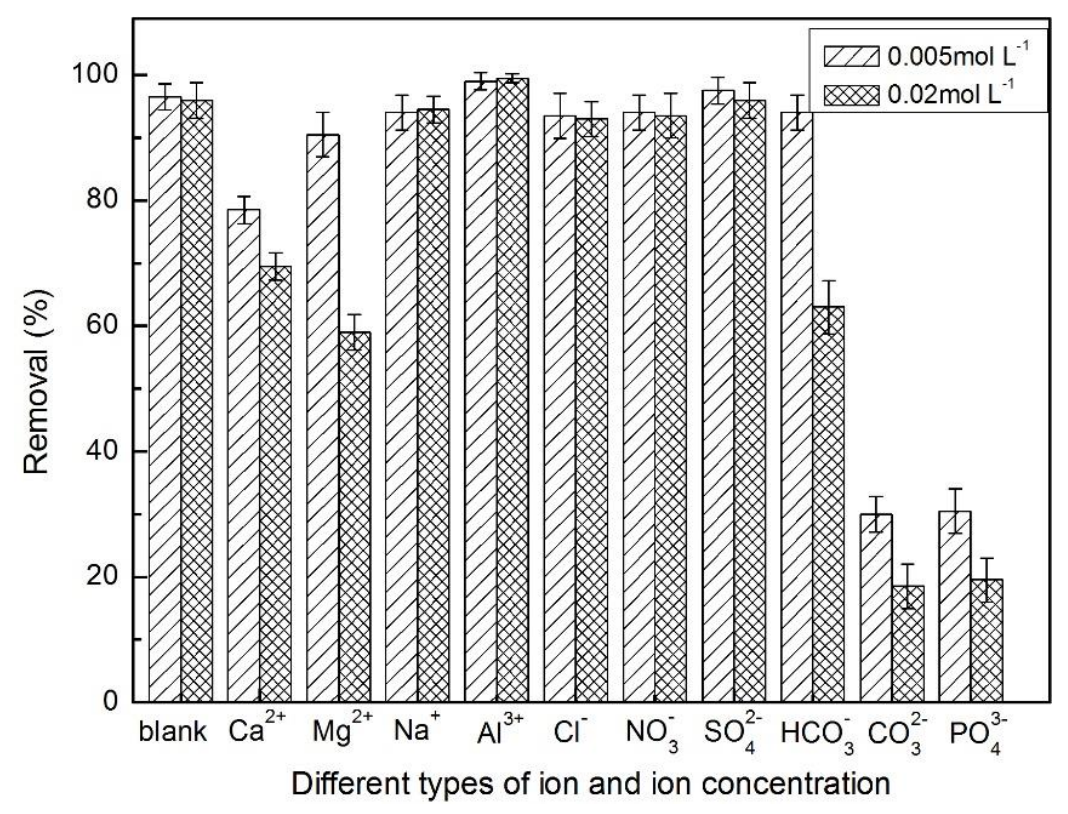

Figure 4. Effect of different types of ion and ion concentration on OTC removal

\subsection{Influence of humic acid}

Natural organic matters are considered to interfere with the OTC removal by ferrate (VI) oxidation. Humic acid is a natural organic matter which is widely present in natural waters. It has large surface areas, complex structure, and with a variety of functional groups $(-\mathrm{COOH},-\mathrm{OH}$, etc.). The chemical structure of humic acids has complexity and diversity and different chemical structure; which will react with various oxidants and result in different chemical reactions. The OTC removal vs coexisting humic acid concentrations is shown in Fig.5. When the concentration of humic acid is less than $10 \mathrm{mg} \cdot \mathrm{I}^{-1}$, the removal efficiency of OTC will not be affected, however with the increase of concentration of humic acid $\left(>10 \mathrm{mg} \mathrm{l}^{-1}\right)$, the removal efficiency of OTC 
gradually reduced. When the concentration of humic acid reaches to $20 \mathrm{mg} \cdot \mathrm{l}^{-1}$, the removal rate dropped from $97 \%$ to $86 \%$ and when it reaches $50 \mathrm{mg} \cdot \mathrm{L}-1$, the removal rate is only $60 \%$. At the same time, humic acid which is not completely oxidized and its reduction product can absorb $\mathrm{Fe}(\mathrm{OH}) 3$, coming from the ferrate decomposition. This will weaken the sorption capacity of $\mathrm{Fe}(\mathrm{OH}) 3$. The removal rate of OTC obviously reduced because of humic acid competition for Fe (VI) with OTC and the competition reactions between reduction product of humic acid and OTC with $\mathrm{Fe}(\mathrm{OH}) 3$.

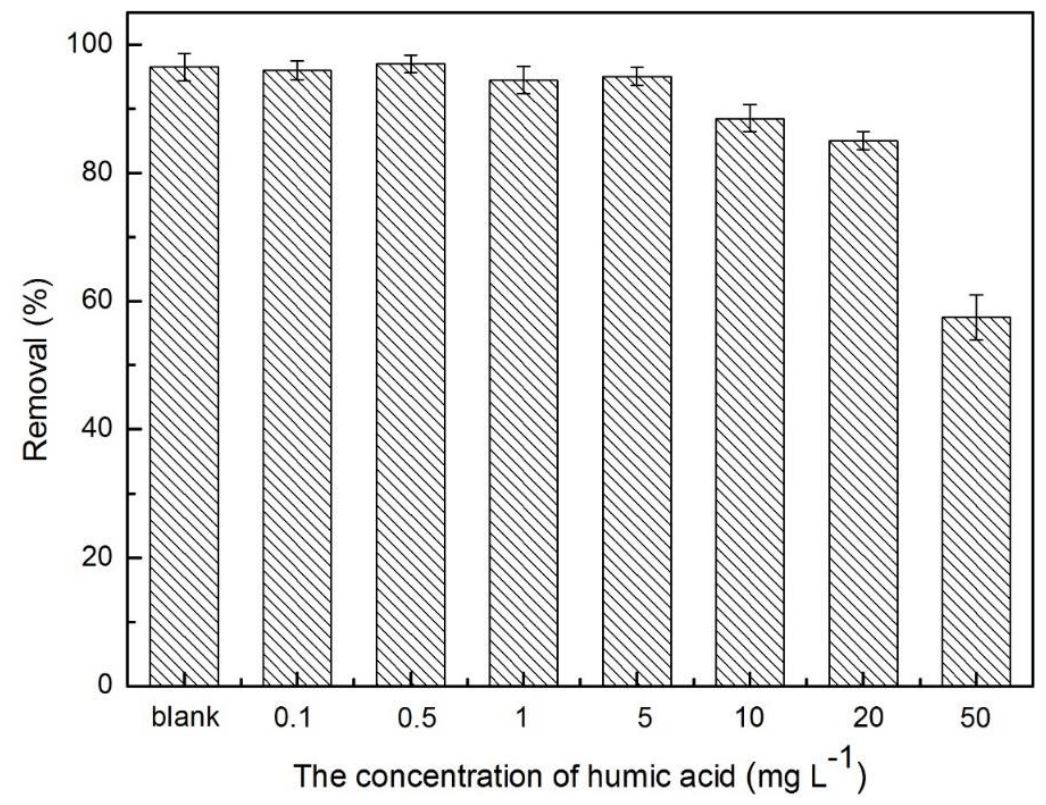

Figure 5. Effect of humic acid on the OTC removal

\subsection{Box-Behnken statistical analysis}

In order to evaluate the effects of various factors on the OTC removal efficiency, a total of 17 experiments were performed. The observed and predicted results are shown in Table 2.The final equation, as shown in Eq. (5), was got in terms of actual factors.

$Y(\%)=94.80+2.50 \times 1+1.50 \times 2-15.75 \times 3+1.25 \times 1 X 2+0.25 \times 1 \times 3-0.75 \times 2 \times 3-0.28 \times 12-1.77 \times 22-30.78 \times 32$

Analysis of variance (ANOVA) was used to test the significance and fitness of the model. The applied ANOVA for the removal of OTC is provided in table 3. The model F-values of 820.16 indicates the model is significant. Values of Prob.>F less than 0.0500 implies mode terms are significant. In this model, A, B, C, AB, B2, C2 is significant. An F-value of 1.43 indicated that the lack of fit is not significant to the pure error and nonsignificant lack of fit is desired. The values of R2, adjusted R2 and predicted R2 are 0.9991, 0.9978 and 0.9914, respectively. The high values of $\mathrm{R} 2$ imply the experimental and predicted results have a strong association.

In order to check the normality of the residuals, data were also analyzed. A normal probability plot or a dot diagram of these residuals is shown in Fig. 6 . The data points on this plot lie reasonably close to a straight line. Fig. 7 shows the relationship between the actual and predicted values of $Y$ for the removal of OTC. The result indicates that the residuals for the prediction for most of the responses are less than $10 \%$, and the residuals tend to be close to the diagonal line, so the developed model is adequate. In summary, the model is appropriate for the explanation of the OTC removal process and could be used in future studies. 
Table 2. Box-Behnken design matrix with predicted and experimental results

\begin{tabular}{cccccc}
\hline \multirow{2}{*}{ Number } & Contact time $(\mathbf{m i n})$ & \multirow{2}{*}{ Ferrate(VI) dose } & \multirow{2}{*}{$\mathbf{p H}$} & \multicolumn{2}{c}{ The OTC removal, $\mathbf{Y}$ (\%) } \\
\cline { 5 - 6 } & & & -1 & 0 observed & predicted \\
\hline 1 & 0 & 0 & -1 & 82.00 & 85.75 \\
\hline 2 & 1 & 0 & 0 & 95.00 & 94.80 \\
\hline 3 & 0 & 0 & 1 & 50.00 & 50.75 \\
\hline 4 & 1 & 1 & 0 & 90.00 & 90.50 \\
\hline 5 & -1 & 0 & 0 & 94.00 & 94.80 \\
\hline 6 & 0 & 1 & 0 & 98.00 & 98.00 \\
\hline 7 & 1 & -1 & 0 & 93.00 & 92.50 \\
\hline 8 & 1 & 1 & -1 & 80.00 & 80.25 \\
\hline 9 & 0 & 0 & 0 & 96.00 & 94.80 \\
\hline 10 & 0 & -1 & -1 & 75.00 & 75.75 \\
\hline 11 & 0 & 0 & 0 & 94.00 & 94.80 \\
\hline 12 & 0 & 0 & 0 & 95.00 & 94.80 \\
\hline 13 & 0 & 0 & 1 & 45.00 & 45.25 \\
\hline 14 & -1 & 0 & -1 & 78.00 & 77.25 \\
\hline 15 & -1 & -1 & 0 & 90.00 & 90.00 \\
\hline 16 & -1 & 1 & 1 & 48.00 & 47.25 \\
\hline 17 & 0 & & &
\end{tabular}

Table 3. ANOVA of the proposed model for the OTC removal

\begin{tabular}{ccccccc}
\hline Source & Sum of squares & df & Mean square & F value & $\begin{array}{l}\text { p-value } \\
\text { prob.>F }\end{array}$ & \\
\hline Model & 6118.08 & 9 & 679.56 & 820.16 & $<0.0001$ & significant \\
\hline $\mathrm{A}-\mathrm{t}$ & 50.00 & 1 & 50.00 & 60.34 & 0.0001 & \\
\hline $\mathrm{B}-\mathrm{d}$ ose & 18.00 & 1 & 18.00 & 21.72 & 0.0023 & \\
\hline $\mathrm{C}-\mathrm{pH}$ & 1984.50 & 1 & 1984.50 & 2395.09 & $<0.0001$ & \\
\hline $\mathrm{AB}$ & 6.25 & 1 & 6.25 & 7.54 & 0.0286 & \\
\hline $\mathrm{AC}$ & 0.25 & 1 & 0.25 & 0.30 & 0.5999 & \\
\hline $\mathrm{BC}$ & 2.25 & 1 & 2.25 & 2.72 & 0.1434 & \\
\hline $\mathrm{A}^{2}$ & 0.32 & 1 & 0.32 & 0.38 & 0.5549 & \\
\hline $\mathrm{B}^{2}$ & 13.27 & 1 & 13.27 & 16.01 & 0.0052 & \\
\hline $\mathrm{C}^{2}$ & 3987.79 & 1 & 3987.79 & 4812.85 & $<0.0001$ & \\
\hline Residual & 5.80 & 7 & 0.83 & & & \\
\hline Lack of fit & 3.00 & 3 & 1.00 & 1.43 & 0.3586 & not significant \\
\hline Pure Error & 2.80 & 4 & 0.70 & & & \\
\hline Cor Total & 6121.88 & 16 & & & &
\end{tabular}

\section{Conclusions}

Results demonstrated that ferrate (VI) could effectively remove OTC in water. When the $\mathrm{pH}$ value of the test solution was 7 and the ferrate (VI) dose was 20:1 as [ferrate(VI)/OTC] in molar ratio, the removal rate of OTC $\left(1000 \mu \mathrm{g} \cdot \mathrm{I}^{-1}\right)$ was $97 \%$ after 30 minutes. The dosage of ferrate $(\mathrm{VI})$ and the $\mathrm{pH}$ value of the reaction solution have a significant impact on the removal rate of OTC. The removal rate increase with the addition of the dosage of ferrate (VI), however, the ability of unit ferrate removal of OTC was decrease, because the 
decomposition rate of ferrate $(\mathrm{VI})$ increased when the dosage of ferrate increased. The $\mathrm{pH}$ of reaction solution had a vital influence on the oxidation ability and the dissociation degree of OTC. Under the conditions of neutral and weak acid, the removal rate of OTC was higher than that under alkaline condition.

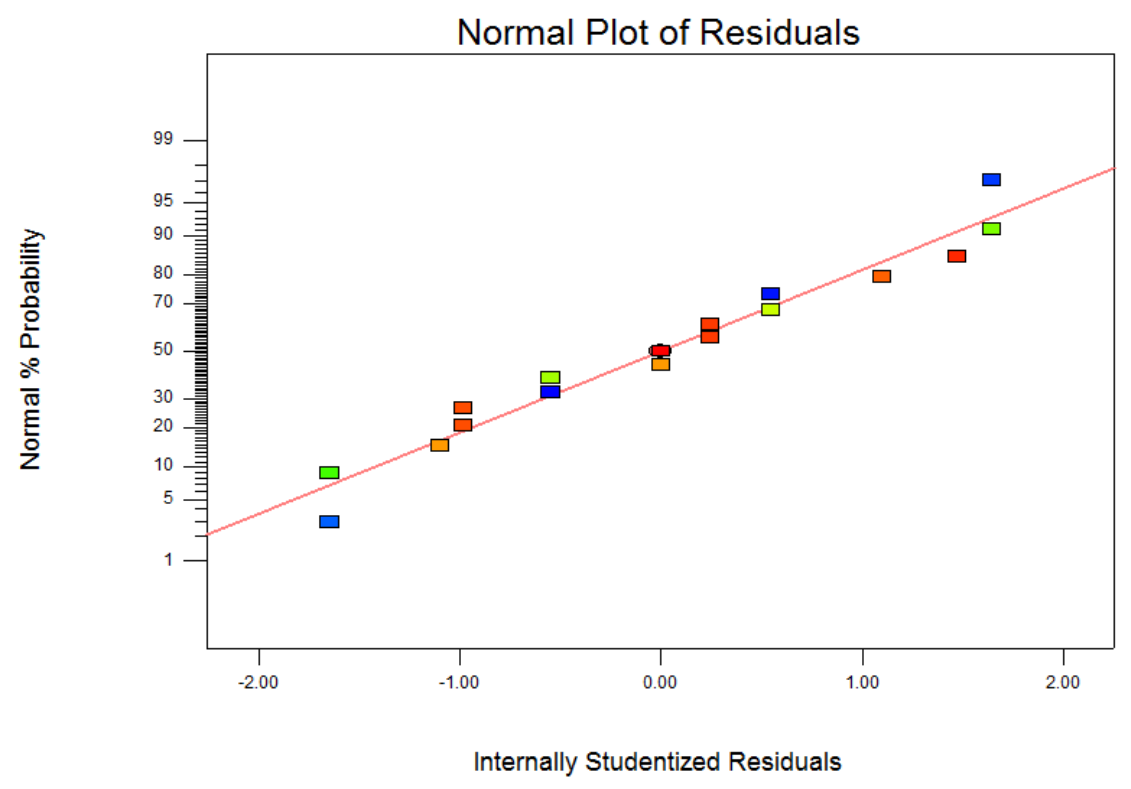

Figure 6. Normal \% probability versus residual error

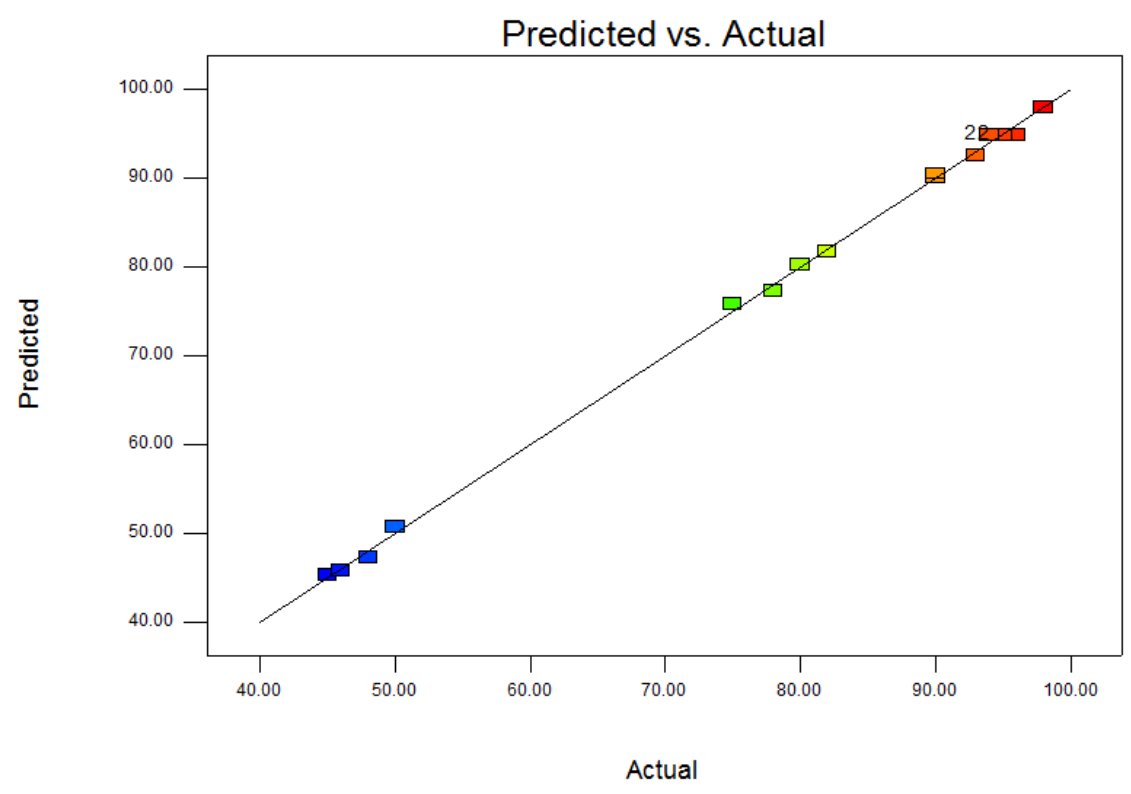

Figure 7. Predicted response versus actual response

The removal rate was highest as the $\mathrm{pH}$ value was 7. Different ion species and concentrations had impact on the OTC removal rate. Calcium ion, carbonate and phosphate restrained the reaction carried out at 0.005 $\mathrm{mol} \cdot \mathrm{l}^{-1}$ and $0.02 \mathrm{~mol} \cdot \mathrm{I}^{-1}$. Magnesium ion and bicarbonate inhibited the reaction conducted at $0.02 \mathrm{~mol}^{-1} \mathrm{I}^{-1}$. Aluminum ion increased the removal rate of OTC. The effect of humic acid on the oxidation of OTC with ferrate was related to its concentration. When the concentration of humic acid was less than 
$10 \mathrm{mg} \cdot \mathrm{l}^{-1}$, the removal rate will not be affected. However when the concentration of humic acid was greater than $10 \mathrm{mg}^{-1}{ }^{-1}$, with the increase of the concentration of humic acid, the removal rate of OTC gradually reduced. Response surface methodology by the Box-Behnken model was used to check the three process factors on the OTC removal. The results showed that second-order polynomial regression model could properly interpret the experimental data with coefficient of determination $\left(R^{2}\right)$ value of 0.9991 and an F-value of 820.16.

\section{Acknowledgments}

The study was supported by Natural Science Foundation of China (NO.21376219).

\section{References}

Auerbach E.A., Seyfried E.E. and McMahon K.D. (2007), Tetracycline resistance genes in activated sludge wastewater treatment plants, Water Research, 41, 1143-1151.

Burkina V., Zlabek V. and Zamaratskaia G. (2015), Effects of pharmaceuticals present in aquatic environment on Phase I metabolism in fish, Environmental Toxicology and Pharmacology, 40, 430-444.

Cesaretti A., Carlotti B., Clementi C., Germani R. and Elisei F. (2014), Effect of micellar and sol-gel media on the spectral and kinetic properties of tetracycline and its complexes with $\mathrm{Mg}^{2+}$, Photochemical and Photobiological Sciences, 13, 509-520.

Chen H., Liu S., Xu X.R., Zhou G.J., Liu S.S., Yue W.Z., Sun K.F. and Ying G.G. (2015), Antibiotics in the coastal environment of the Hailing Bay region, South China Sea: Spatial distribution, source analysis and ecological risks, Marine Pollution Bulletin, 95, 365-373.

Chen Y., Hu C., Qu J. and Yang M. (2008), Photodegradation of tetracycline and formation of reactive oxygen species in aqueous tetracycline solution under simulated sunlight irradiation, Journal of Photochemistry and Photobiology A: Chemistry, 197, 81-87.

Figueroa R.A., Leonard A. and Mackay A.A. (2004), Modeling tetracycline antibiotic sorption to clays, Environmental Science and Technology, 38, 476-483.

Fritz J.W. and Zuo Y.G. (2007), Simultaneous determination of tetracycline, oxytetracycline, and 4-epitetracycline in milk by high-performance liquid chromatography, Food Chemistry, 105, 1297-1301.

Jain A., Sharma V.K. and Mbuya O.S. (2009), Removal of arsenite by Fe(VI), $\mathrm{Fe}(\mathrm{VI}) / \mathrm{Fe}(\mathrm{III})$, and $\mathrm{Fe}(\mathrm{VI}) / \mathrm{Al}(\mathrm{III})$ salts: effect of $\mathrm{pH}$ and anions, Journal of Hazardous Materials, 169, 339-344.

Jian J.Q., Wang S. and Panagoulopoulos A. (2006), The exploration of potassium ferrate(VI) as a disinfectant/coagulant in water and wastewater treatment, Chemosphere, 63, 212-219.

Jiang J.Q. (2014), Advances in the development and application of ferrate (VI) for water and wastewater treatment, Journal of Chemical Technology and Biotechnology, 89, 165-177.

Jiang J.Q., Zhou Z.W. and Pahl O. (2012), Preliminary study of ciprofloxacin (cip) removal by potassium ferrate (VI), Separation and Purification Technology, 88, 95-98.

Jiao S.J., Meng S.R., Yin D.Q., Wang L.H. and Chen L.Y. (2008), Aqueous oxytetracycline degradation and the toxicity change of degradation compounds in photoirradiation process, Journal of Environmental Sciences, 20, 806-813.

Kemper N. (2008), Veterinary antibiotics in the aquatic and terrestrial environment, Ecological Indicators, 8, 1-13.

Kim C.H., Lee L.P., Min J.R., Lim M.W. and Jeong S.H. (2014), An indirect competitive assay-based aptasensor for detection of oxytetracycline in milk, Biosensors and Bioelectronics, 51, 426-430.

Kuemmerer K. (2009), Antibiotics in the aquatic environment - A review - Part I, Chemosphere, 75, 417-434.

Li C., Li X.Z. and Graham N. (2005), A study of the preparation and reactivity of potassium ferrate, Chemosphere, 61, 537543. 
Li K., Yediler A., Yang M., Schulte-Hosted S. and Wong M.H. (2008), Ozonation of oxytetracycline and toxicological assessment of its oxidation by-products, Chemosphere, 72, 473-478.

Li Z., Xiang X., Li M., Ma Y.P., Wang J.H. and Liu X. (2015), Occurrence and risk assessment of pharmaceuticals and personal care products and endocrine disrupting chemicals in reclaimed water and receiving groundwater in China, Ecotoxicology and Environmental Safety, 119,74-80.

Liu Y.Q., He X.X., Duan X.D., Fu Y.S. and Dionysiou D.D. (2015), Photochemical degradation of oxytetracycline: Influence of $\mathrm{pH}$ and role of carbonate radical, Chemical Engineering Journal, 276, 113-121.

Lu C., Tang Z., Liu C., Kang L. and Sun F. (2015), Magnetic-nanobead-based competitive enzyme-linked aptamer assay for the analysis of oxytetracycline in food, Analytical and Bioananalytical Chemistry, 407, 4155-4163.

Luis Martinez J. (2009), Environmental pollution by antibiotics and by antibiotic resistance determinants, Environmental Pollution, 157, 2893-2902.

Marx C., Mühlbauer V., Krebs P. and Kuehn V. (2015), Environmental risk assessment of antibiotics including synergistic and antagonistic combination effects, Science of the Total Environment, 524, 269-279.

Mourabet M., El Rhilassi A., El Boujaady H., Bennani-Ziatni M., El Hamri R. and Taitai A. (2012), Removal of fluoride from aqueous solution by adsorption on Apatitic tricalcium phosphate using Box-Behnken design and desirability function, Applied Surface Science, 258, 4402-4410.

Paroloa M.E., Avenab M.J., Pettinaria G.R. and Baschini M.T. (2012), Influence of Ca ${ }^{2+}$ on tetracycline adsorption on montmorillonite, Journal of Colloid and Interface Science, 368, 420-426

Rahmah A.U., Harimurti S., Omar A.A. and Murugesan T. (2015), Kinetics, and Thermodynamic Studies of Oxytetracycline Mineralization Using UV/H2O2, Clean-Soil Air Water, 43, 496-503.

Sharma V.K., Mishra S.K. and Nesnas N. (2006), Oxidation of sulfonamide antimicrobials by ferrate $(\mathrm{VI})\left[\left(\mathrm{Fe}{ }^{\mathrm{VI}} \mathrm{O}_{4}{ }^{2-}\right)\right]+$, Environmental Science and Technology, 40, 7222-7227.

Shibata K., Amemiya T. and Itoh K. (2014), Effects of oxytetracycline on populations and community metabolism of an aquatic microcosm, Ecological Research, 29, 401-410.

Su C.M. and Suarez D.L. (1997), In situ infrared speciation of absorbed carbonate on aluminum and iron oxide, Clay and Clay Minerals, 45, 814-825.

Sun J.Y., Gan T., Zhu H.J., Shi Z.X. and Liu Y.M. (2014), Direct electrochemical sensing for oxytetracycline in food using a zinc cation-exchanged montmorillonite, Applied Clay Science, 101, 598-603.

Uslu M.O. and Balcioglu I.A. (2009), Comparison of the ozonation and Fenton process performance for the treatment of antibiotic containing manure, Science of the Total Environment, 407, 3450-3458.

Wang H.Y., Liu Y.B, Zeng F.C. and Song S. (2015), Electrochemical synthesis of ferrate (VI) by regular anodic replacement, International Journal of Electrochemical Science, 10, 7966-7976.

Watkinson A.J., Murby E.J. and Costanzo S.D. (2007), Removal of antibiotics in conventional and advanced wastewater treatment: Implications for environmental discharge and wastewater recycling, Water Research, 41, 4164-4176.

Yuan F., Hu C., Hu X., Wei D., Chen Y. and Qu J. (2011), Photodegradation and toxicity changes of antibiotics in UV and $\mathrm{UV} / \mathrm{H}_{2} \mathrm{O}_{2}$ process, Journal of Hazardous Materials, 185, 1256-1263. 